\title{
The Effect of Flipped Classroom Instruction on Enhancing English Grammar and Vocabulary Learning for Secondary Commercial Schools' Graduates \\ Heba M. Abdullah
}

TEFL Lecturer. Faculty of Graduate Studies for Education, Cairo University (email.heba_mustafa@cu.edu.eg)

\section{Abstract}

The study aimed to investigate the effect of flipped classroom instruction on enhancing grammar and vocabulary learning of secondary commercial school graduates enrolled in a preparation course for obtaining a Commercial Diploma Equivalency Certificate (CDEC), Cairo University. The CDEC preparation course is designed in the light of EFL teaching goals specified by Ministry of Education for general secondary schools to prepare commercial school graduates for studying in higher education settings. The study used the quasi-experimental design. The sample of the study consisted of fifty-eight students assigned to two group; 29 controls, 29 experimental. Instruments included two equivalent grammar and vocabulary tests. The Implementation of the proposed program took a period of seven weeks. Despite drawbacks and challenges, results of the study revealed the positive impact of flipped classroom instruction on enhancing grammar and vocabulary learning for secondary commercial school graduates.

\section{Keywords}

Flipped Classroom Instruction; Vocabulary Learning; Grammar Learning

\section{Introduction}

Changes in the conceptualization of language education have led to instructional methods that embrace technology as a teaching medium. Recently, there has been a fast-growing interest in exploring issues related to flipped classrooms and their applications in English as a Foreign Language (EFL) fields. The basic premise beyond flipped classrooms is not completely new. According to Delozier and Rhodes (2016: p. 1), "Flipped classroom refers to the practice of assigning lectures outside the class, and devoting class time to a variety of learning activities". That is, the learning content is not presented during the class time, rather is learned by students themselves before attending classes. 
Conversely, home assignments and extended practices take place in class time. Thus, the traditional model of instruction is 'inverted', 'reversed' or 'flipped' (Bhatt-Mackin \& Gagliardi, 2016; Egbert et al.,2015).

Recently, there have been many attempts to present a definite pedagogical description of flipped classroom instruction. Splitting it into phases, Long et. al (2016) define flipped classroom instruction as an instructional model that encompasses pre-class learning phase and 'inclass learning phase' (p. 2). Another research adopts a functional perspective where flipped classroom frameworks are considered as formats. Blair et al. (2016) describe flipped classroom instruction as a format that entails restructuring classroom activities. In the same line of thinking, McNally et al. (2016) focus on the manner of organizing and planning activities (both pre-class and in-class). Hence, it is viewed as a teaching strategy.

In a broader sense, a flipped classroom framework is described as an instructional approach that embraces varied potential pedagogical practices rooted in the constructive theory (Hawks, 2014). That is, flipped classroom instruction is based on two main premises of the constructive theory of learning. Firstly, learners should construct knowledge individually as well as collaboratively. Secondly, the learning process is highly supported by feedback. In addition, Vygotsky's concept of the zone of proximal development (ZPD) is represented in the substantial development of varies types of interaction patterns within a class; i.e, teacher/student, student/student (Correa, 2015).

Numerous combinations of flipped classroom instruction course designs came to exist, i.e., micro flipping (Bvemi, 2014), flipped team based learning (Camiel et al., 2016)and self-regulated flipped classroom (Moos \& Bonde, 2016). As far as this study is concerned, flipped classroom instruction is defined as an instructional approach grounded on the constructivism. Its underpinning premises is the establishment of a learning environment that entails knowledge construction prior to in-class learning experiences. Classroom experiences are limited to guided or independent practice rather than new content exploration. 


\section{Heba M. Abdullah}

\section{Flipped classroom instruction principles}

Although there is no single design, there are common aspects that characterize the effective flipped classroom instruction Among which are the following;

1- Extended classroom learning environment: within the flipped classroom instruction, the learning environment encompasses both inclass and pre-class activities. The 'flipped classroom' concept extends to include traditional classroom settings and online learning platforms (Bergman \& Sams,2012; Ng, 2014).

2- Differentiated instructional practices: the flipped classroom, in its comprehensive sense, involves the intentional use of innovative multimedia formats and online resources to meet learners' varied styles and preferences. In addition, learning materials are to be organized in accordance with a careful plan that addresses learners with high abilities as well as low achievers and at risk students (Finkel, 2012; Flumerfelt \& Green, 2013).

3- Personalized action plan: The flipped classroom allows content to be delivered at a learner's pace rather than a group learning pace. Content is accessed and manipulated on demand (Bergmann \& Sams, 2013; Defour, 2013).

4- Student-centered activities: A flipped classroom involves more interaction and less direct instruction. Class time is totally maximized to incorporate numerous patterns of students' engagement and interaction (Betihavas et al., 2016; Bergmann \& Sams, 2014).

5- Assessment as learning: varied assessment tools are employed to guide learners to mastery levels. Quizzes with automated feedback help with the reconstructing of knowledge and the rebuilding of understanding. Varied forms of assessment including peer and selfmonitoring are promoted to ensure deeper learning (Bergmann, 2016a, 2016b).

\section{Pedagogical implications}

The literature on the research into pedagogy and application of flipping classroom instruction has revealed four basic implications (Hao \& Lee, 2016; McCrea, 2016; Moffett, 2015; Sajid et al., 2016; Wolff \& Chan,2016). Firstly, learning culture underpins a remarkable shift towards autonomous learning. Learning is a self-directed and regulated 
process with a consensus support from parents, teachers, and community. Secondly, Learning resources are characterized by being highly interactive and accessible. Learners can access materials on demand. In addition, content is displayed via screencasting software resulting in unlimited resource formats that cater to various learners.

Thirdly, Learners' engagement in pre-class experiences indicates their promising levels of academic performance. Yet, individualized learning potential benefits are supported by social learning practice, namely, peer assessment, team-based skills, collaboration and peer learning. Fourthly, the role of teachers is redefined to encompass the development of a set of technological skills, related to; video production, screen casting, script writing, web administrating, question banking development, curriculum designing.

Other implications have been drawn from the findings of empirical studies reporting on the effectiveness of flipped classroom instruction across a wide area of learning; mathematics (Bhagat et. al., 2016), libraries (Fowley, 2014), medical education (Khanova et al., 2015), community service (Maloy et al., 2014). Based on their results flipped classroom instruction is highly recommended for implementation.

Yet, research on flipped classroom instruction is still in a nascent stage with respect to EFL education. Egbert et al. (2015, p.1) assert that "reports of flipped classrooms across areas in the ESL are rare". Moreover, Mehring (2015, p.1) states "unfortunately, there is little research which supports the incorporation of flipped classroom instruction in the EFL classroom. Numerous studies have focused on flipped classroom instruction and other subject areas, but more research needs to be done on EFL classroom".

In fact, current research on flipped classroom instruction and EFL education has highlighted its effectiveness with regard to the enhancement of some distinct language skills, particularly; writing (Andres, 2016; Arduser, 2016; Campbell, 2016; Cummings, 2016; Gasmi, 2016), oral skills (Hsich et al., 2016; Jehma, 2016), reading (Huong \& Hong, 2016). Furthermore, other studies investigated the effect of flipped instruction based language courses on the learners' language achievement, namely, EFL literature (Gross, 2014), EAP (Soliman, 


\section{Heba M. Abdullah}

2016), ESP (Liu, 2016), and a university EFL course (Webb et al., 2014). These studies proved its positive impact and reported a tangible progress in learners' level of achievement. Holding a comprehensive view of FL learning processes, several studies indicated potential benefits of the implementation of flipped classroom instruction, particularly, motivation (Yu \& L. Yu, 2016), attitude (Doman \& Webb, 2016), and readiness (Hao, 2016).

In addition to the previously mentioned studies, Ishikowa et. al. (2014) explores findings of a project intended to improve students' scores on the TOEIC test through flipped classroom instruction. A group of students completed a suggested TOEIC preparation course for a period of months. Results showed that the flipped classroom instruction improved students' TOEIC scores.

To conclude, there are empirical reports on the positive impact of the implementation of flipped classroom instruction on the EFL learning process in general, and the enhancement of learners' language skills and achievement levels. Yet, there is a need for further investigation with respect to EFL education. Consequently, the researcher suggests the use of flipped classroom instruction for developing grammar and vocabulary learning for commercial schools' graduates enrolled in the CDEC preparation course.

\section{Grammar and Vocabulary Learning}

The strong position of grammar and vocabulary development as components of EFL learning process continues to be supported by educational research (Yue \& Fan, 2016; Rowley, 2010). Drawing on language acquisition theories, many strong arguments for teaching grammar and vocabulary have arisen (Wach, 2011, Siyanova-Chanturia $\&$ Webb, 2016). Yet, there are several controversial matters about the choice of teaching procedures that govern the optimal instruction process. Accordingly, theorists and researchers have put forward several pedagogical paradigms and methodologies for developing grammar and vocabulary learning in EFL contexts.

Considering grammar instruction, there has been numerous teaching approach because of the controversy of placing emphasis on form rather than meaning, and vice versa. Obviously, explicit and implicit grammar instruction are based on form-focused practices as the best 
option to promote optimal learning process. Within both paradigms, learners undergo mental processes (, i.e., infer or deduce) aimed at provoking the accurate use of grammar rules (Azad \& Shanta, 2012; Corzo, 2013). In contrast, meaning is the prime focus of communicative grammar instruction. Its main aim is to promote language production that is fluent and coherent (Lai, 2009). According to Mystkowska-Wiertelak and Pawlak (2012), approaches to grammar instruction can be put together into two main opposite trends, namely; production-oriented and comprehension based paradigms.

Taking account of the trends outlined above, numerous empirical attempts tried to find out the most appropriate choice in an EFL context. Hence, the findings of some studies shed light on the effectiveness of several grammar teaching practices within specific settings, such as; taskbased grammar instruction (J.Huang, 2010), web-based comic strip (K1lıckaya \& Krajka 2012), PACE Model (Kretzschmar, 2011), automated approach (Lyddon, 2012), simulations (McPhilomy, 2014), note-taking (Slagter, 2010) and corpus-informed instruction (Smart, 2012).

Regarding vocabulary learning, there have been two main teaching approaches; namely, form-focused instruction, and meaning-focused instruction. Form-focused vocabulary teaching practices, same as grammar, aim at developing declarative knowledge explicitly or implicitly (Torres, 2015; Wolf, 2013). As for meaning-focused instruction, it aims at fostering procedural knowledge developed through comprehension and communicative practice (Huffman, 2010). However, it is noteworthy to clarify the difference between two main terms; learning and acquisition. Vocabulary 'learning' is characterized fundamentally by consciousness, where learners undergo intentional processes of manipulating knowledge (declarative, procedural).In other words, both form-focused and meaning-focused practices are important to the process of vocabulary learning (Sawada, 2009; Yahia \& Sinatra, 2013).

On the other hand, vocabulary 'acquisition' is marked by the unconscious process of internalizing of incidental vocabulary (Gallego \& Llach, 2009; S.Huang, 2010). In this study, vocabulary learning is defined 


\section{Heba M. Abdullah}

as an EFL leaner's ability to recognize various context clues (definition, examples, synonym, antonym) and identify word parts, namely; prefix and suffix (whereas grammar learning refers to the accurate recognition of verb tenses and parts of speech).

Recent research has investigated not only vocabulary learning but also vocabulary size on grounds of corpus linguistics theories (Aljuhoni, 2016; Wolfe, 2015). In addition, vocabulary learning strategies have received prominent attention, by researchers (Kulikova, 2015; Mahiques, 2014). Furthermore, supported by research findings, numerous practices for developing vocabulary learning have been investigated. Among which; mobile based games (Alzahrani, 2015), electronic dialogue (Ahmed, 2013), repeated reading, (Brandes, 2015), multimedia (Villegas \& Izquierdo, 2014), structured think-aloud technique (Ebner, 2012), TPRS (Espinoza, 2015), computer games (Feng, 2009), interactive whiteboard (Martin, 2015), authentic songs (Metaxa, 2013), shared readings (Rivas, 2011), keyword method (Shaman, 2015), INVIT (Taylor, 2012), cartoon drawings (Thomas, 2013), graphic organizers (Tsubaki, 2012), mediation tools (Walter, 2016); vocabulary portfolio (Widodo, 2016), and literature based group discussions (Willingham, 2009).

Based on what has been mentioned above, it is concluded that grammar and vocabulary learning has been given great prominence in relation to theory and practice. That can be attributed to their important role in FL learning process (Isiah, 2016; Johnson, 2015; Khalifa, 2015). Despite such significance to EFL teaching/learning, grammar and vocabulary instruction are mostly neglected areas in relation to Arab EFL learners (Al-Quran, 2010; El-Dakhs, 2015; Kripps, 2013; Reda, 2015), in general, and in Egyptian EFL contexts (AbdelMaksoud, 1994; Al-Dagel, 2009; Al-Hazemi, 1998; El-Bassuony , 2011; Jadullah \& Nabhan , 2013), in particular.

\section{Context of the problem}

The current study is designed to investigate the development of English grammar and vocabulary learning for secondary commercial school graduates via the use a program based on flipped classroom instruction. After the completion of the secondary stage in commercial schools, graduates enroll in a preparation course for obtaining a Commercial Diploma Equivalency Certificate (CDEC). This course aims 
at preparing graduates of secondary commercial schools for studying in higher education settings by achieving the goals specified by the Ministry of Education for the secondary stage in the general government schools. The researcher has worked as an English teacher in secondary commercial schools for two years. During this time, the researcher noticed that students' mastery level of grammar and vocabulary was low. Whilst the aims of EFL teaching, as assigned by the Ministry of Education for general secondary stage students placed a higher emphasis on grammar and vocabulary learning than those ascribed to commercial schools. EFL syllabuses in commercial schools are specialized and include functional vocabulary and linguistic patterns. Hence, students who enroll in the CDEC preparation course suffer at low mastery level of the grammar and vocabulary required to pass the CDEC examination. Thus, motivating researcher to conduct the pilot study described in this paper. A questionnaire was administered to 10 faculty staff who taught in the CDEC preparation course in previous years. The questionnaire was divided into three sections; general information, items concerning students' mastery level of vocabulary and grammar, and items related to the methods of teaching. The results revealed the students' low mastery of grammar and vocabulary. It also indicated:

(a) CDEC English Courses are taught in oversized classes where mentoring students is difficult.

(b) Lecturing is the only used technique.

(c) Vocabulary learning is based on memorization and retention.

(d) The explicit explanation is the only technique used to teach grammar.

(e) Class time is very limited resulting in few student/ student interactions.

(f) Feedback is rarely given individually.

(g) Class time as devoted to lecturing and controlled practice.

(h) Home assignments include extended practice.

\section{Statement of the problem:}

The problem to be investigated by the present study is the low mastery level in English grammar and vocabulary learning of secondary commercial school graduates enrolled in the CDEC preparation course.

The current study attempts to answer the following question: 
What is the effect of flipped classroom instruction on enhancing grammar and vocabulary learning for secondary commercial school graduates enrolled in the CDEC preparation course?

\section{Hypothesis of the study}

1- There is a statistically significant difference between the mean scores of the experimental and the control group students in the administration of the grammar and vocabulary posttest in favor of the experimental group.

2- There is a statistically significant difference between the mean scores of the experimental group students on the administrations of the grammar and vocabulary pre and posttests in favor of the posttest administration.

\section{Method}

\section{Participants}

The study was conducted at Cairo University with graduates of secondary commercial schools who were enrolled in a CDEC preparation Course in July 2016. There were fifty-eight participants $(\mathrm{N}=58)$ who were assigned into two group; the control $(\mathrm{n}=29)$ and the experimental $(n=29)$. The sample included new graduates who had obtained a mean English test score of (25) in their Egyptian secondary commercial schools' certifications. It is noteworthy that their total English test score was (50).

\section{Instruments}

The researcher designed two equivalent tests for assessing the participants' level of mastery of grammar and vocabulary before and after the implementation of the program. Each form was comprised of twenty items with total marks (100) (See appendix A for test specifications). The researcher conducted a pilot study to determine the reliability of the tests prior to the experiment. They were administered to a group of 100 students. Results were obtained and calculated using Cronbach's Alpha. It was (0.744), significant at 0.001 level.

\section{Procedures}

Prior to the implementation of the treatment, the administration of the grammar and vocabulary pre-test took place with both groups. As for the experimental group, the test was followed by a questionnaire that assessed the computer skills required for pre-class activities. It is 
noteworthy that participants reported that they had taken an advanced computer course as a basic requirement for graduation whilst studying in their secondary commercial schools.

The implementation of the proposed flipped instruction based program was over a period of seven weeks. Both the control and experimental group participants were enrolled in the same CDEC preparation course and were taught by the researcher simultaneously. The control group was taught in the traditional way where sessions included a direct explanation of grammar and vocabulary followed by controlled practices and home assignments. On the other hand, the experimental group was taught via a flipped instruction based program. In the traditional classroom, the researcher This program consisted of twelve units that comprise twenty-four lessons. Each unit took a two-hours session and covered two lessons; namely; grammar and vocabulary. The researcher met the experimental group twice a week for a total duration of forty-eight hours across the whole implementation. Before undertaking the experimental program, a session was held to explain the optional and mandatory pre-class activities and provide participants an opportunity to prepare and ask questions. In addition, the researcher provided a demonstration of the online activities and discussed the anticipated problems that they may encounter (see appendix B for the unit design). At the end of the program (both traditional and experimental), a grammar and vocabulary posttest was administered to both groups.

\section{Results}

All data were statistically treated using Statistical Package for Social Science (SPSS) T-test and Eta square. namely; independent t-test, paired sample t-test, and Eta square. Prior to conducting the experiment, it was essential to investigate if there were any statistically significant differences among participations in respect to their level of mastery of English vocabulary and grammar. Hence, results of administration of the pretest were analyzed using independent samples t-test.

Table 1. T-Test Results of Administration of The Grammar and Vocabulary Pre- Test Comparing the Control and Experimental Groups

Mean Scores.

\begin{tabular}{|l|l|l|r|l|l|l|l|}
\hline Group & $\mathbf{N}$ & Mean & Std. Deviation & T & DF & Sig & Eta \\
\hline Control & 29 & 15.5433 & 5.14332 & .064 & 56 & .865 & .004 \\
\cline { 1 - 5 } Experimental & 29 & 14.4828 & 8.16622 & & & & \\
\hline
\end{tabular}




\section{Heba M. Abdullah}

As indicated in table (1), there were no statistically significant differences between the mean scores of the experimental and control groups on the administration of the grammar and vocabulary pretest, i.e., the estimated t-value was (0.64) which is not significant at 0.01 level. Hence, it could be said that both groups were homogenous in terms of the level of the students' level of mastery of grammar and vocabulary before conducting the experiment.

In respect to the first hypothesis, mean scores of the experimental and control groups on the administration of the grammar and vocabulary posttest were compared using independent t-test as shown in table (2)

Table 2. T-Test Results of Administration of the Grammar and Vocabulary

Posttest Comparing the Control and Experimental Groups Mean Scores.

\begin{tabular}{|l|l|l|r|l|l|l|l|}
\hline Group & N & Mean & Std. Deviation & T & DF & Sig & Eta \\
\hline Control & 29 & 15.5172 & 8.48789 & 17.308 & 56 & .000 & .903 \\
\cline { 1 - 5 } Experimental & 29 & 75.8621 & 16.74755 & & & & \\
\hline
\end{tabular}

Results showed that there were statistically significant differences at 0.01 level in favor of the experimental group, i.e., estimated t-value is (17.308).

To verify the second hypothesis, paired sample t-test was conducted for comparing mean scores of the experimental group students on the administrations of pretest and posttest of English grammar and vocabulary.

Table 3. T-Test Results of Administrations of the grammar and vocabulary pretest and posttest Comparing Experimental Group Students' Mean Scores.

\begin{tabular}{|c|c|c|c|c|c|c|c|c|}
\hline \multicolumn{2}{|l|}{ Item } & $\mathbf{N}$ & Mean & Std. & $\mathbf{T}$ & DF & Sig & Eta \\
\hline \multirow[t]{2}{*}{ Vocabulary } & Pre & \multirow[b]{2}{*}{29} & 8.7765 & 3.85434 & \multirow[t]{2}{*}{18.151} & \multirow[t]{2}{*}{28} & \multirow[t]{2}{*}{.000} & \multirow[t]{2}{*}{.865} \\
\hline & Post & & 30.6897 & 7.64434 & & & & \\
\hline \multirow[t]{2}{*}{ Grammar } & Pre & \multirow[b]{2}{*}{29} & 7.2414 & 2.60392 & \multirow[t]{2}{*}{21.722} & \multirow[t]{2}{*}{28} & \multirow[t]{2}{*}{.000} & \multirow[t]{2}{*}{.886} \\
\hline & Post & & 45.1724 & 11.76274 & & & & \\
\hline \multirow{2}{*}{$\begin{array}{l}\text { Grammar } \\
\& \\
\text { Vocabulary }\end{array}$} & Pre & \multirow[b]{2}{*}{29} & 14.4828 & 8.16622 & \multirow[t]{2}{*}{24.625} & \multirow[t]{2}{*}{28} & \multirow[t]{2}{*}{.000} & \multirow[t]{2}{*}{.875} \\
\hline & Post & & 75.8621 & 16.74755 & & & & \\
\hline
\end{tabular}

The previous table (3) shows that there were statistically significant differences between the mean scores of the experimental group on the administrations of pretest and posttest of English grammar and vocabulary in favor of the posttest administration, since the estimated tvalue for the grammar and vocabulary learning was (24.625) Hence, it 
The Effect of Flipped Classroom Instruction on Enhancing English Grammar and Vocabulary Learning for Secondary Commercial Schools' Graduates

was indicated that using the flipped classroom instruction had a large effect on enhancing the experimental group students' grammar and vocabulary learning.

\section{Discussion}

Results of the study have shown that the proposed flipped instruction based program had a large effect on developing English grammar and vocabulary learning $(\eta 2=0.875)$. This was proved by comparing scores of the experimental and control groups on the administration of grammar and vocabulary posttest using T-test ( $\mathrm{t}=$ 17.308). Hence, results of the current study are consistent with the results of previous studies that indicated the effectiveness of flipped classroom instruction on developing some language skills and the language acquisition process (Andres, 2016; Arduser, 2016; Campbell, 2016; Cummings, 2016; Doman \& Webb, 2016; Gasmi, 2016; Gross, 2014; Hao, 2016;Hsieh et al., 2016; Huang \& Hong, 2016; Jehma, 2016; Li, 2016; Soliman, 2016; Webb et. al., 2014 ; Yu \& L. Yu, 2016).

Taking into account students responses in the retrospective discussion at the end of each session, students' progress can be ascribed to several factors. The well-planned introductory session was very beneficial to the students. In this session, the researcher provided students with a full description of the program including objectives, unit design, and activity instructions and requirements. This resulted in the students becoming familiar with the objectives of their learning process. In turn, they showed interest in taking on the responsibility of their learning. In addition, students' knowledge about the unit format paved the way for a self-directed learning process. Moreover, units were organized in a logical sequence where completion of the previous unit is a condition for progressing further.

Also, units access was timed with respect to an announced schedule of the sessions. They have to participate in pre-class activities before attending the session, otherwise, access is denied. Hence, students were encouraged to be focused and disciplined with respect to the timing of completions of units. They became aware of the workload required in relation to a session's objectives. The illustration of the activities instructions was also helpful. It clarified the exact required action that 
would contribute to the successful completion of an activity. Furthermore, the demonstration of the platform, including the website map, interactive tutorials, welcoming vodcast, and syllabus assured students' readiness to participate. It increased students' familiarity with the utilized website interface which, in turn, provoked feelings of relief about its usage. Finally, solutions for anticipated technical problems were discussed. It had been declared that all services provided by the platform could be obtained via mobile devices. Students were highly interested in using their mobile devices to access the platform.

Other factors that may have contributed to students' tangible progress were much related to the design of the flipped classroom instruction. As for the pre-class activities, there were a lot of flexibility in exploring of the learning material. Content had been offered in varied formats including videos, PowerPoint presentations, and texts. Such variety was intended to meet students' different preferences and learning styles. In addition, each format provided the researcher with numerous options for adjusting the content in relation to easiness and simplicity. Moreover, audio recordings that accompanied the videos and the narrated PowerPoint presentations were in students' mother tongue, i.e., Arabic language. Hence, explanations were provided in both languages so as to meet students' different preferences. Another aspect that represented flexibility was the ability to access material online or offline, i.e. without an internet connection.

Furthermore, students had the option to stop, pause, fast, forward or rewind the videos or PowerPoints as many times as they want. Such flexibility provided an opportunity for students to learn at their own pace. In fact, cognitive processes required for knowledge construction were personalized according to the students' individual learing paces. One potential advantage of such flexibility was the ability to personalize one's own learning. This aspect may be considered one of the primary motives for the students' engagement in the pre-class activities. Students were highly interested in the pre-class activities as they used to participate more than once and via different formats.

In respect to the recordings (videos and narrated PowerPoints), some factors can be highlighted. Recordings had been created and administered in accordance with the general guidelines for their 
educational production (Hunt,2013; Raths,2013). Firstly, recordings were short (7-10 mins) enough to maintain students' attention throughout the whole duration. Secondly, content was split to help students absorb information better without overloading the working memory. That is, one concept was covered in each recording. Thirdly, recordings were wellstructured. Each recording started with an introduction stating objectives and ended up with a summary. Such a structure helped students to reconstruct knowledge in a comfortable way.

Other specific factors that were related to the use of 'automated formative quizzes' in the pre-class activities. Quizzes were based on the content presented in videos or PowerPoint presentations. Thus, quizzes were focused and only accessed individually. Quizzes were accompanied with immediate feedback. Automated feedback included explanations as well as corrections. This aspect supported the students' construction of knowledge as it helped the rebuilding processes of prior knowledge. It also promoted self-assessment and reflection and provided opportunities for students to develop a better understanding. In turn, students were encouraged to be active participant outside and inside classroom.

Regarding in-class activities, some factors can be highlighted. Firstly, 'the question and answer' activity was based on the students' automated feedback printouts of quizzes. After they were handed their feedback reports, students could ask questions freely. Thus, they were triggered to ask clarification about their misconceptions and reorganize their knowledge. Consequently, they became ready for more extended activities that developed their understanding of the topic. Secondly, the use of "text-based activities" was beneficial. Traditionally, these kinds of activities were thought to the best drill for exam preparation. In addition, students were used to these kinds of activities. Thus, they prepared for more focused and active participation. Thirdly, the "Reading handout" activity was useful for summarization and consolidation. They were handed a concise summary to read, modify or elaborate on.

\section{Drawbacks and challenges}

The implementation of the flipped classroom instruction was hindered by some problems. One main problem raised by some students was a reluctance to continue the program. The initial experimental group 


\section{Heba M. Abdullah}

included 35 students. Despite receiving very good feedback in nearly three successive sessions, six students left the group citing the following reasons:

- Despite the interesting content and activities, exam issues were not considered. Content objectives were clear but the exam was vague and not covered in detail.

- Despite receiving very good automated feedback, students were suspicious about their performance. They believed that only the teacher provides trusted feedback.

- Students' parents were annoyed and convinced that pre-class activities were a waste of time. Due to the exam being written, learning should be done in the same format with a lot of home assignment.

- Some students felt anxious about the idea of learning new content without being monitored by a teacher. Despite their excellent automated feedback, they underestimated their performances.

- Some students found pre-class activities time-consuming. They were used to studying similar content in less time.

However, after conducting an interview with each student. The researcher interpreted the problems and applied the following solutions:

- Students were used to learning for passing exams. They needed to know the exam format and distribution of marks. Hence, the researcher designed the remained of the quizzes using the same final exam format.

- Students were used to a highly prescriptive way of teaching. Retention and memorization were the main emphasized cognitive processes. Thus, knowledge construction seemed to be timeconsuming. The researcher started to award students after the completion of each unit by the end of the session. These certifications were much appreciated by the students and most of their parents.

- Due to being used to a teacher-centered classroom setting, the students were highly dependent. They were used to a teacher's presence even if no help is provided. The researcher declared that students' performances were being monitored daily. Such a declaration gave them a sense of relief. 
- Traditionally, textbooks were used as the only resource for information. Thus, any other resources seemed to be waste of time. The researcher repeatedly highlighted that textbooks were the commonly used source but still, there were other options which may be even more beneficial.

- Students were accustomed to one form of assessment. Feedback was only given by the teacher. Other forms of assessment (peerself) were totally neglected in traditional classroom settings. The researcher had to sign each printout of automated feedback quizzes before being handed to students.

\section{Conclusions}

Based on the previous discussion the study provided evidence on the positive effect of using flipped classroom instruction on enhancing English grammar and vocabulary learning of commercial school graduates enrolled in the CDEC preparation course $(\eta 2=0.849)$. Students tangible progress can be attributed to numerous factors in relation to the program, unit design, recordings, and activities. Challenges that faced the implementation of the suggested program were successfully handled. However, the following aspects should be considered when flipped classroom instruction is applied:

- Flipped classroom instruction requires a careful reorganization of the content. Concepts should be split into their simplest form and covered separately.

- Flipped classroom instruction requires a substantial effort by teachers to develop the smart use of digital technologies. It needs a reasonable amount of time to create different formats of the same content.

- Flipped classroom instruction embraces the designing of activities with a varied degree of challenges ranging from basic cognitive processes towards higher order thinking skills.

- Flipped classroom instruction might be best implemented via gradual intervals. Hence, students' familiarity with its practices grows with time. 


\section{Heba M. Abdullah}

\section{References}

Abdelmaksoud, Z. (1994). The Effect of Role Play on The Achievement of Secondary School Students in Vocabulary and Grammatical Structures. Studies in Curriculum and Methodology, Ain Shams University, 95, 74 - 97

Ahmad, A. (2013). The Effect of WhatsApp Electronic Dialogue Journaling on Improving Writing Vocabulary Word Choice and Voice of EFL Undergraduate Saudi Students. Arab World English Journal,4(3),213-225.

Al-Dagel, S. R. (2009). EFL Vocabulary Learning and Teaching Problems and Techniques. Faculty of Education Quarterly, Ain Shams University, $33(3), 1-26$

Al-Hazemi, H. (1998). A new Testing Procedure for Measuring Vocabulary from The Learning: A Case Study Of Arab Learners Of English As A Foreign Language. Faculty of Education Quarterly, Elazhar University, 73,1-9

Aljuhani, H. (2016). Using corpora in a lexicalized stylistics approach to teaching English-as-a-foreign-language literature. Ann Arbor, California State University, San Bernardino. 10113094: 213.

Al-Quran, M. (2010). Concept-Based Grammatical Errors of Arab EFL Learners. Journal of Instructional Psychology, 37(1), 3-12.

Alzahrani, H. (2015). Examining the Effectiveness of Utilizing Mobile Technology in Vocabulary Development for Language Learners. Arab World English Journal, 6(3), 108-119.

Anders, A. (2016). Flipping the Composing Process: Collaborative Drafting and Résumé Writing. Business and Professional Communication Quarterly, 79(1), 102-118.

Arduser, L. (2016). Flipping the Class: A New Media Pedagogy. Business and Professional Communication Quarterly,79(2), 217-233.

Azad, A. \& Shanta, S. (2012). Teaching Grammar to the Undergraduate Bangladeshi EFL Learners: A Rethinking. ASA University Review, 6(2), 117-128.

Bergmann J. (2016a). The Flipped Class: Formative Assessment. Retrieved from https://youtu.be/nzvZjMcL2dQ

Bergmann, J. \& Sams, A. (2013). Flipping for Mastery. Educational Leadership, 71(4), 24-29.

Bergmann, J. \& Sams, A. (2014). Flipped Learning: Maximizing FaceTime. $T+D, 68(2), 28-31$.

Bergmann, j. (2016b). The Flipped Class and Mastery Checks. Retrieved from https://youtu.be/qR8QurhNngA

Bergmann, J., \& Sams, A. (2012). Flip Your Classroom: Reach Every Student in Every Class Every Day. Washington, DC: ISTE.

Betihavas, V. et al. (2016). The Evidence for 'Flipping Out': A Systematic Review of the Flipped Classroom in Nursing Education. Nurse Education Today, 38, 15-21. 
The Effect of Flipped Classroom Instruction on Enhancing English Grammar and Vocabulary Learning for Secondary Commercial Schools' Graduates

Bhagat, K. et al. (2016). The Impact of the Flipped Classroom on Mathematics Concept Learning in High School. Journal of Educational Technology \& Society, 19(3), 134-142.

Bhatt-Mackin, S. \& Gagliardi, J. (2016). Flipping the Academic Half-Day to Create an Opportunity for Faculty Development. Academic Psychiatry, 40(4), 617-619.

Blair, E. et al. (2016). Performance and Perception in the Flipped Classroom. Education and Information Technologies, 21(6), 1465-1482.

Brandes, D. (2015). Repeated Reading with and without Vocabulary Instruction: Outcomes for English Language Learners. Ann Arbor, University of Minnesota. 3727800: 194.

Camiel, L. et al. (2016). Students' Attitudes, Academic Performance and Preferences for Content Delivery in a Very Large Self-Care Course Redesign. American Journal of Pharmaceutical Education,80(4), 18.

Campbell, K. S. (2016). Flipping to Teach the Conceptual Foundations of Successful Workplace Writing. Business and Professional Communication Quarterly,79(1), 54-67.

Correa, M. (2015). Flipping the Foreign Language Classroom and Critical Pedagogies: A (New) Old Trend. Higher Education for the Future, 2(2), 114-125.

Corzo, C. (2013). Formal Grammar Instruction: Theoretical Aspects to Contemplate Its Teaching. Profile: Issues in Teachers' Professional Development, 15(2), 215-224.

Cummings, L. (2016). Flipping the Online Classroom with Web 2.0: The Asynchronous Workshop. Business and Professional Communication Quarterly,79(1), 81-101.

Defour, M. (2013). Flipped Classrooms' Spreading in Wisconsin. Community College Week, 25(16), 10-10.

DeLozier, S. \& Rhodes, G. (2016). Flipped Classrooms: A Review of Key Ideas and Recommendations for Practice. Educational Psychology Review, 1-11.

Doman, E. \& Webb, M. (2016). The Flipped Experience for Chinese University Students Studying English as a Foreign Language. TESOL Journal, doi:10.1002/tesj.264.

Ebner, R. (2012). Using the Internet with a Structured Think-Aloud Methodology to Enhance College Students' Vocabulary. Ann Arbor, City University of New York. 3508670: 175.

Egbert, J. et al. (2015). Flipped Instruction in English Language Teacher Education: A Design-Based Study in a Complex, Open-Ended Learning Environment. TESL-EJ,19(2), 1-23.

El-Bassuony, J. M. (2011). A Program Based on Mental Imagery to Develop English Vocabulary of EFL Primary School Slow Learners. Studies in Curriculum and Methodology, Ain Shams University, 170, 1-45 


\section{Heba M. Abdullah}

El-Dakhs, D. (2015). Collocational Competence in English Language Teaching: An Overview. Arab World English Journal,6(1), 68-82.

Espinoza, P. (2015). Three Teachers' Experiences Developing and Implementing Teaching Proficiency through Reading and Storytelling (TPRS) Curriculum in their World Language Classes. Ann Arbor, Chapman University. 1605751: 83.

Feng, L. (2009). How Do Adult Foreign Language Learners Experience the Opportunities Presented by Computer Games as A Self-Study Tool? Ann Arbor, University of Massachusetts Lowell. 3357576: 295.

Finkel, E. (2012). Flipping the Script in K12. District Administration, 48(10), 28-34.

Flumerfelt, S. \& Green, G. (2013). Using Lean in the Flipped Classroom for At-Risk Students. Journal of Educational Technology \& Society, 16(1), 356-366.

Gallego, M. \& Llach, M. (2009). Exploring the Increase of Receptive Vocabulary Knowledge in the Foreign Language: A Longitudinal Study. International Journal of English Studies, 9(1), 113-133.

Gasmi, A. (2016). An Exploratory Study of Students' Lived Experiences in a Blended-Flipped Writing Class. Arab World English Journal, (3), 210-226.

Gross, A. (2014). The Flipped Classroom: Shakespeare in the English Classroom. Ann Arbor, North Dakota State University. 1569865: 85.

Hao, Y. \& Lee, S. (2016). "Teaching in flipped classrooms: Exploring preservice teachers' concerns. Computers in Human Behavior, 57,250260.

Hao, Y. (2016). Middle School Students' Flipped Learning Readiness in Foreign Language Classrooms: Exploring Its Relationship with Personal Characteristics and Individual Circumstances. Computers in Human Behavior, 59, 295-303.

Hawks, S. (2014). The Flipped Classroom: Now or Never? AANA Journal,82(4), 264-269.

Hsieh, J. et al. (2016). Using the Flipped Classroom to Enhance EFL Learning. Computer Assisted Language Learning, 1-25.

Huang, J. (2010). Grammar Instruction for Adult English Language Learners: A Task-Based Learning Framework. Journal of Adult Education,39(1), 29-37.

Huang, S. (2010). Effects of Tasks and Glosses on L2 Incidental Vocabulary Learning: Meta-analyses. Ann Arbor, Texas A\&M University. 3436800: 142.

Huang, Y. \& Hong, Z. (2016). The Effects of a Flipped English Classroom Intervention on Students' Information and Communication Technology and English Reading Comprehension. Educational Technology Research and Development, 64(2), 175-193. 
The Effect of Flipped Classroom Instruction on Enhancing English Grammar and Vocabulary Learning for Secondary Commercial Schools' Graduates

Huffman, S. (2010). The Influence of Collaboration on Attitudes Towards English Vocabulary Learning. Ann Arbor, Iowa State University. 1476305: 146.

Hunt, M. W. (2013). Video and Sound Production: Flip out! Game on! Techniques. Connecting Education and Careers, 88(1),36-38.

Ishikowa, Y. et al. (2014). Flipped Learning in a University EFL Course: Helping Students Improve their TOEIC Scores. Inted2014: 8th International Technology, Education, and Development Conference. Valencia, TATED-Int Assoc Technology Education and Development.

Isiah, R. (2016). Teacher Implementation and Impact of Academic Vocabulary Instructional Protocols for Long Term English Learners. Ann Arbor, Loyola Marymount University. 10101046: 85.

Jadullah,M. \& Nabhan,F.(2013).Promoting Language Awareness and Avoiding Misconceptions in Teaching Grammar to EFL Students with Special Reference to the Past Perfect. Faculty of Arts Quarterly, Ain Shams University, (41), 574-559.

Jehma, H. (2016). Flipped Learning as an English Communicative Skill Development Tool for EFL Learners in Thailand. Man in India, 96(1-2), 609-616.

Johnson, L. (2015). Vocabulary Strategies in an Elementary Classroom in a Third World Country. Ann Arbor, Walden University. 3683346: 119.

Khalifa, S. (2015). Effect of Vocabulary Learning Strategies on Academic Achievements of Pre-University Libyan EFL Learners. Arab World English Journal,6(1), 378-396.

Khanova, J. et al. (2015). "Student Experiences Across Multiple Flipped Courses in A Single Curriculum." Medical Education ,49(10), 10381048.

Kilıçkaya, F. \& Krajka, J. (2012). Can the Use of Web-Based Comic Strip Creation Tool Facilitate EFL learners' Grammar and Sentence Writing? British Journal of Educational Technology, 43(6), 161165.

Kretzschmar, M. (2011). The Emphasis of Formal Grammar Teaching in Second Language Programs: The natural Approach through Children's Literature. Ann Arbor, University of Wyoming. 1491891: 109.

Kripps, A. (2013). Vocabulary Building for Arab Learners. Perspectives,20(3), 14-20.

Kulikova, O. (2015). Vocabulary Learning Strategies and Beliefs about Vocabulary Learning: A Study of Beginning University Students of Russian in the United States. Ann Arbor, The University of Iowa. 3726903: 296. 
Lai, Y. (2009). The Effects of Grammar Translation Method and Communicative Language Teaching Grammar Instruction in EFL University Students in Taiwan. Ann Arbor, Alliant International University, San Diego. 3374770: 171.

Liu, D. (2016). The Reform and Innovation of English Course: A Coherent Whole of MOOC, Flipped Classroom and ESP. Procedia - Social and Behavioral Sciences, 232, 280-286.

Long, T. et al. (2016). Use of the Flipped Classroom Instructional Model in Higher Education: Instructors' Perspectives. Journal of Computing in Higher Education, 1-22.

Lyddon, P. (2012). An Evaluation of an Automated Approach to ConceptBased Grammar Instruction. European Association for ComputerAssisted Language Learning (EUROCALL).

Mahiques, E. (2014). Vocabulary Learning Strategies Abroad and At Home. Ann Arbor, University of Delaware. 1562385: 81.

Maloy, R. et al. (2014). Wikis, Workshops, and Writing: Strategies for Flipping a College Community Engagement Course. Journal of Educators Online, 11(1),1-23.

Martin, C. (2015). Teaching Vocabulary Development Using Interactive Whiteboards to Third Grade ELL Students in the United Arab Emirates. Ann Arbor, University of Florida. 10102507: 165.

McCrea, B. (2016). Four Ways Schools are Overcoming Flipped Learning Equity Challenges." THE Journal, 43(3), 26-27.

McNally, B. et al. (2016). Flipped Classroom Experiences: Student Preferences and Flip Strategy in a Higher Education Context. Higher Education, 1-18.

McPhilomy, S. (2014). Using Role-Plays and Simulations to Motivate ESL Students in a Grammar Class: A Case Study. Ann Arbor, University of Phoenix. 3583312: 168.

Mehring, J. (2016). Present Research on the Flipped Classroom and Potential Tools for the EFL Classroom. Computers in the Schools,33(1), 1-10.

Metaxa, X. (2013). The Effect of Authentic Songs on Vocabulary Acquisition in the English Foreign Language Classroom. Ann Arbor, Saint Louis University. 3587358: 146.

Moffett, J. (2015). Twelve Tips for Flipping the Classroom. Medical Teacher,37(4), 331-336.

Moos, D. \& Bonde, C. (2016). Flipping the Classroom: Embedding SelfRegulated Learning Prompts in Videos. Technology, Knowledge and Learning, 21(2), 225-242.

Mystkowska-Wiertelak, A. \& Pawlak, M. (2012). Issues in Grammar Learning and Teaching. Berlin, Heidelberg, Springer.

Ng, W. (2014). Flipping the Science Classroom: Exploring Merits, Issues, and Pedagogy. Teaching Science, 60(3), 16-27.

Raths, D. (2013). 9 Video Tips for a Better Flipped Classroom. THE Journal, $40(11), 12-18$. 
The Effect of Flipped Classroom Instruction on Enhancing English Grammar and Vocabulary Learning for Secondary Commercial Schools' Graduates

Reda, G. (2015). A Review of the Cognitive Linguistics Approach to Teaching the EFL/EIL Vocabulary. Arab World English Journal,6(2), 189200.

Rivas, B. (2011). Vocabulary Development through Shared Readings: The Potential Role of Explicit Instruction and Supplemental Multimedia in the Preschool ELL Classroom. Ann Arbor, Southern Methodist University. 3519468: 185.

Rowley, A. (2010). The Role of Grammar Knowledge for Identifying Language Needs. Ann Arbor, the State University of New York at Albany. 3402683: 199.

Sajid, M. et al. (2016). Can Blended Learning and the Flipped Classroom Improve Student Learning and Satisfaction in Saudi Arabia? International Journal of Medical Education, 7,281-285.

Sawada, K. (2009). Vocabulary Acquisition Through Listening and Its Relation To Learning Channel Preferences. Ann Arbor, Temple University. 3371998: 188.

Shaman, S. (2015). Using the Expanded Keyword Method to Help K-12 Students Develop Vocabulary Knowledge. Ann Arbor, Washington State University. 3717472: 90.

Siyanova-Chanturia, A. \& Webb, S. (2016). Teaching Vocabulary in the EFL Context. In W. A. Renandya and H. P. Widodo (Eds.). English Language Teaching Today: Linking Theory and Practice (pp. 227239). Cham, Springer International Publishing.

Slagter, R. (2010). Teaching Grammar through Application: How Focusing on Application in Class and Note-Taking Outside of Class Affects Learning Grammar. Ann Arbor, Southwest Minnesota State University. 1485050: 56.

Smart, J. (2012). Innovative Approaches to ESL Grammar Instruction. Ann Arbor, Northern Arizona University. 3524406: 168.

Soliman, N. (2016). Teaching English for Academic Purposes via the Flipped Learning Approach. Procedia - Social and Behavioral Sciences, 232, 122-129.

Taylor, P. (2012). An Evaluation of the Intensive Vocabulary Immersion Technique for Critical Course Vocabulary Instruction. Ann Arbor, Walden University. 3540353: 172.

Thomas, S. (2013). Improving Vocabulary Acquisition and Reading Comprehension Through Cartoon Drawing Instruction Method. Ann Arbor, Walden University. 3602542: 93.

Torres, M. (2015). The Effects of Explicit Vocabulary Instruction on the Vocabulary Development of English Language Learners in Kindergarten. Ann Arbor, Northcentral University. 3689479: 141.

Tsubaki, M. (2012). Vocabulary Learning with Graphic Organizers in The EFL Environment: Inquiry Into The Involvement Load Hypothesis. Ann Arbor, Temple University. 3494138: 317. 


\section{Heba M. Abdullah}

Villegas, V. \& Izquierdo, J. (2014). Multimedia and Second Language Vocabulary: Study with University-level Learners of English1. Sinéctica, 42,1-12.

Wach, A. (2011). Grammar Instruction in ELT: Insights from the Classroom. Berlin, Heidelberg, Springer.

Walter, B. (2016). Vocabulary Mediation in The Second Language Classroom: An Exploratory Study. Ann Arbor, The Florida State University. 10120514: 114.

Webb, M. et al. (2014). Flipping a Chinese University EFL course: What Students and Teachers Think of the Model, TESOL Quarterly 11(4), 53-84.

Widodo, H. (2016). The ESP Vocabulary Portfolio as a Tool for Sustained Vocabulary Learning. Issues in Materials Development. Rotterdam, Sense Publishers

Willingham, D. (2009). Enhancing Community College Students' Vocabulary Acquisition: Literature Discussion Groups in Developmental Classes. Ann Arbor, Sam Houston State University. 3362004: 174.

Wolf, J. (2013). The Effects of Elaborative Vocabulary Instruction on The Vocabulary, Written Explanations, And Knowledge Structures Of Sixth-Grade Students With And Without Disabilities. Ann Arbor, University of San Francisco. 3595813: 190.

Wolfe, J. (2015). The TED Word List: An Analysis of TED Talks to Benefit ESL Teachers and Learners. Ann Arbor, Royal Roads University (Canada). 10006500: 93.

Wolff, L. \& Chan, J. (2016). How to Develop Flipped Classrooms? Flipped Classrooms for Legal Education. Singapore, Springer

Yahia, E. \& Sinatra, R. (2013). Vocabulary Development Strategies for the L2 Classroom. Arab World English Journal,4(2), 152-159.

Yu, Z. \& Yu, L. (2016). Correlations Between Learners' Initial EFL Proficiency and Variables of Clicker-Aided Flipped EFL Class. Education and Information Technologies, 1-17.

Yue, Y. \& Fan, S. (2016). Measurement of Vocabulary Knowledge. What is Next in Educational Research? Rotterdam, Sense Publishers. 
The Effect of Flipped Classroom Instruction on Enhancing English Grammar and Vocabulary Learning for Secondary Commercial Schools' Graduates 